\title{
Glycerin for New Biodiesel Formulation
}

\author{
A. Jaecker-Voirol' ', I. Durand ${ }^{2}$, G. Hillion'2, B. Delfort ${ }^{2}$ and X. Montagne' \\ 1 Institut français du pétrole, IFP, Direction Techniques d'Applications Énergétiques, \\ 1-4 avenue de Bois-Préau, 92852 Rueil Malmaison Cedex - France \\ 2 Institut français du pétrole, IFP, Direction Chimie et Physico-Chimie Appliquées, \\ 1-4 avenue de Bois-Préau, 92852 Rueil Malmaison Cedex - France \\ e-mail: anne.jaecker@ifp.fr - isabelle.durand@ifp.fr - gérard.hillion@ifp.fr - bruno.delfort@ifp.fr - xavier.montagne@ifp.fr
}

\begin{abstract}
Résumé - Formulation d'un nouveau biocarburant Diesel à base de glycérol - Les biocarburants sont une alternative intéressante pour limiter les émissions de gaz à effet de serre, améliorer la qualité de l'air et trouver de nouvelles ressources énergétiques. Pour les moteurs Diesel, les esters d'huiles végétales, provenant de la transestérification des huiles végétales, ont montré leur potentiel comme carburants alternatifs. Toutefois, la transestérification engendre systématiquement la formation de glycérine (ou glycérol). Trouver un débouché, pour ce glycérol, est fondamental pour la filière des esters d'huiles végétales. En parallèle, les composés oxygénés ont montré leur potentiel pour réduire les émissions de particules des moteurs Diesel. Transformer le glycérol en un dérivé oxygéné, miscible au gazole, pourrait être une solution très prometteuse.

Différents composés oxygénés dérivés du glycérol, tels que des acétals, des éthers et des carbonates ont été synthétisés et évalués en mélange dans du gazole. Notre objectif était d'évaluer leur potentiel par rapport à des mélanges contenant de l'EMC (Ester Méthylique de Colza), en terme d'émissions de polluants sur différentes technologies moteurs, et de sélectionner le plus prometteur. Le GTBE (ter-butyl ethers de glycérol) s'est avéré le plus intéressant et a été mélangé avec du biodiesel tout en restant dans les limites des critères physico-chimiques de la norme EN 14214. Ce nouveau biocarburant $(92,5 \%$ $\mathrm{EMC}+7,5 \%$ GTBE $+1000 \mathrm{ppm}$ pro cetane) a été incorporé dans du gazole à hauteur de $5 \%$ vol. et comparé à un mélange contenant $5 \%$ d'EMC. Après différents tests menés sur véhicule et sur moteur, en se focalisant sur les émissions de polluants et d'éventuels problèmes d'encrassement, nous pouvons conclure que l'utilisation de ce nouveau biocarburant ne présente pas d'inconvénient technique. La décision d'utiliser ce dérivé du glycérol dans la formulation des gazoles sera donc gouvernée par des critères économiques.
\end{abstract}

\begin{abstract}
Glycerin for New Biodiesel Formulation - Biofuels are an important way of progress for limiting greenhouse gas emissions, improving air quality and finding new energetic resources. For diesel engines, FAE (Fatty Acid Ester), coming from transesterification of vegetable oils, have shown their potentials as fuel substitutes. Nevertheless, this transesterification induces the production of glycerin (or glycerol) as fatal co-product. Finding an outlet to this glycerol is fundamental for the FAE network. In the same time, oxygenated compounds have been shown to have great potential for the reduction of diesel particulate emissions. Transforming glycerol into new oxygenated compounds, which could be formulated with diesel fuel, would be a very promising way.
\end{abstract}

Different oxygenates derived from glycerol, such as acetals, ethers and carbonates, have been synthesized and evaluated as blending components for Diesel fuel. Our objective was to evaluate their 
potential, compared with RME (Rapseed Methyl Ester) blends in term of pollutant emissions with different new engine technologies and to select the most promising of them. GTBE (Glycerol Ter Butyl Ether) was the most interesting compound and it was formulated with biodiesel with the respect of the physicochemical criteria required by EN14214 standard. This new biofuel $(92.5 \%$ RME $+7.5 \%$ GTBE + 1000 ppm pro cetane) was incorporated in diesel fuel (5\% vol.) and compared with a mixture containing $5 \%$ RME. After various tests carried out on vehicle and engine, focusing on pollutant emissions and possible fouling problems, it is possible to conclude that this new biodiesel does not present any technical disadvantage. The decision to use this glycerol derivatives in diesel fuel formulation will thus be controlled by economical criteria.

\section{LIST OF ABBREVIATIONS}

$\begin{array}{ll}\text { EMC } & \text { Ester Méthylique de Colza } \\ \text { FAE } & \text { Fatty Acid Ester } \\ \text { FAME } & \text { Fatty Acid Methyl Ester } \\ \text { RME } & \text { Rapseed Methyl Ester } \\ \text { GTBE } & \text { Glycerol Ter Butyl Ether } \\ \text { NEDC } & \text { New European Driving Cycle } \\ \text { ECE } & \text { Urban part of NEDC cycle } \\ \text { EUDC } & \text { Extra Urban part of NEDC Cycle }\end{array}$

\section{INTRODUCTION}

For Diesel engines, the reduction of particulate emissions is an important challenge in which car manufacturers and oil companies combine their efforts. National and European authorities are responsible for establishing, and verifying that the air quality standards are respected.

Different solutions are investigated:

- Developments in the engine technologies, like post-treatment, common rail, etc.;

- Improvement in the Diesel fuel quality;

- Fuel reformulation incorporating specific oxygenated compounds.

Among the technological solutions, fuel injection, under very high pressure, directly in the combustion chamber allows emission reductions. This technology is available on recent vehicles. For the improvement of fuel quality, the sulfur reduction allows a significant reduction in particulate mass emissions. Today, in Europe, the maximum authorized sulfur content is $50 \mathrm{ppm}$ and will be $10 \mathrm{ppm}$ in 2009 . Fuel reformulation by incorporating some oxygenated compounds is also a promising way to decrease particulate emissions of Diesel vehicles. FAME (Fatty Acid Methyl Ester), coming from transesterification of vegetable oils, have shown their potential as fuel substitutes. However, this transesterification induces glycerol production as fatal co-product.

Our objective was to identify and to synthesize some oxygenated glycerol derivatives which could be blended with Diesel fuel. Their potential in terms of pollutant emissions has been evaluated with different engine technologies.

\section{STATE OF THE ART}

Biodiesel is an alternative fuel that is technically known as Fatty Acid Methyl Ester (FAME). FAME including vegetable derived esters are increasingly being used as extenders to or replacements of diesel fuel. This has been driven largely by national efforts to exploit agricultural products and/or to reduce the dependency on imported oil products.

Many oils may be used for making methyl esters: fresh vegetable oil (rapeseed, sunflower, palm, soya etc.), waste oil from restaurants and industrial processes and animal fats. The most common source of biodiesel is soya in the USA and rapeseed in Europe.

In the USA, the most common blend has been $20 \%$ biodiesel and $80 \%$ conventional diesel fuel [1]. But blends containing 5\% biodiesel are commonly accepted for use in existing diesel engines by engine and fuel injection equipment manufacturers.

The main advantages of FAME are:

- They are biofuels and it is helpful for reducing the greenhouse effect unlike fossil fuels;

- They contain no sulfur and no aromatics;

- They reduce exhaust gas particulate matter [2];

- They ensure lubricity of injection equipment [3].

However, when they are used at high levels of concentration [4]:

- Risk of deposit formations could appear, so treatment with detergent additive is advisable;

- Seals and composite materials have to be monitored in the fuel system in order to avoid any degradation unless they are specially chosen for their compatibility;

- Oxidation stability and total innocuity with the injection system must be controlled (risk of varnish deposit);

- The dilution of engine lubricant must be controlled. There are different chemical reactions leading to fatty acid methyl esters:

- Base - catalyzed transesterification of the oil with methanol;

- Direct acid - catalyzed esterification of the oil with methanol;

- Conversion of the oils to fatty acids and then to alkyl esters with acid catalysis. 
$\mathrm{R} \cdot \mathrm{COO}-\mathrm{CH}_{2}$
$\mathrm{R}-\mathrm{COO}-\mathrm{CH}_{2}+\mathrm{CH}_{3}+\mathrm{COO}-\mathrm{CH}_{3} \mathrm{OH} \stackrel{\text { CAT }}{=}$

vegetable oil methanol

Figure 1

FAME production scheme.

Industrial processes have used the base catalyzed reaction. A synthetic scheme is given Figure 1.

Glycerol is a by-product of the transesterification reaction:

$1 \mathrm{t} \mathrm{Oil}+0.1 \mathrm{t} \mathrm{MeOH}=>1 \mathrm{t}$ FAME $+0.1 \mathrm{t}$ glycerol
The Directive 2003/30/CE [5] has imposed a planning for the introduction of minimal volume of fuels resulting from the biomass (biocarburant). From 2\% (energetic equivalent) in 2005 , it is necessary to reach $5.75 \%$ of the fuels sold in 2010. As biodiesel production grows, an extra amount of glycerol reaches the market. The challenge is to find an economically profitable outlet for this glycerol, to avoid its price crash and then an increase for biodiesel price.

The synthesis of components starting from glycerol, miscible in Diesel fuel would be an very interesting solution.

As it is well known, oxygenated compounds could improve Diesel fuel performance [6, 7]. They induce reduction in particulate emissions and/or improvement in cetane index of the fuel [8-10]. Among the chemical structures having this potential [11], we will quote mainly ethers, acetals and carbonates.

TABLE 1

The different glycerol derivatives and tested fuels

\begin{tabular}{|c|c|c|c|c|c|c|c|c|c|}
\hline \multicolumn{5}{|c|}{ Characteristics of Glycerol derivatives } & \multicolumn{5}{|c|}{ Characteristics of tested fuels } \\
\hline & $\begin{array}{l}\text { Name of main } \\
\text { products }\end{array}$ & $\begin{array}{l}\text { Obtained by reaction } \\
\text { of glycerol with }\end{array}$ & $\begin{array}{l}\mathrm{O} \% \\
(\% \mathrm{w})\end{array}$ & $\begin{array}{l}\text { Density } \\
\left(\mathrm{kg} / \mathrm{m}^{3}\right)\end{array}$ & \%vol in $\mathrm{RF}$ & $\begin{array}{l}\mathrm{C} \% \\
(\% \mathrm{w})\end{array}$ & $\begin{array}{l}\mathrm{H} \% \\
(\% \mathrm{w})\end{array}$ & $\begin{array}{l}\mathrm{O} \% \\
(\% \mathrm{w})\end{array}$ & $\begin{array}{l}\text { Density } \\
\left(\mathrm{kg} / \mathrm{m}^{3}\right)\end{array}$ \\
\hline GBA* & Glycerol Butyl Acetal & Butyraldehyde & 33.6 & 1055 & $\begin{array}{c}5 \% \text { RF1 } \\
5 \% \text { RF2 } \\
10 \% \text { RF2 }\end{array}$ & $\begin{array}{l}84.4 \\
84.3 \\
82.4\end{array}$ & $\begin{array}{l}13.2 \\
13.3 \\
13.1\end{array}$ & $\begin{array}{l}2.1 \\
2.4 \\
4.4\end{array}$ & $\begin{array}{l}847 \\
850 \\
863\end{array}$ \\
\hline GBAC & $\begin{array}{c}\text { Carbonate of Glycerol } \\
\text { Butyl Acetal }\end{array}$ & $\begin{array}{l}\text { 1) Butyraldehyde } \\
\text { 2) Diethylcarbonate }\end{array}$ & 36.4 & 1100 & $5 \% \mathrm{RF} 1$ & 85.7 & 13.1 & 1.6 & 852 \\
\hline GEA & $\begin{array}{c}\text { Glycerol Ethyl } \\
\text { Acetal }\end{array}$ & Di Ethoxy 1.1 Ethane & 36.7 & 1076 & $\begin{array}{l}5 \% \mathrm{RF} 1 \\
5 \% \mathrm{RF} 2\end{array}$ & $\begin{array}{l}84.2 \\
84.0\end{array}$ & $\begin{array}{l}1.31 \\
13.2 \\
\end{array}$ & $\begin{array}{l}2.4 \\
2.6\end{array}$ & $\begin{array}{l}849 \\
853\end{array}$ \\
\hline GFTBE & $\begin{array}{c}\text { Glycerol Formal Ter } \\
\text { Butyl Ether }\end{array}$ & $\begin{array}{l}\text { 1) Formaldehyde } \\
\text { 2) Isobutene }\end{array}$ & 30.4 & 995 & $5 \% \mathrm{RF} 2$ & 84.5 & 13.2 & 2.4 & 850 \\
\hline GFEA & $\begin{array}{c}\text { Glycerol Formal } \\
\text { Ethyl Acetal }\end{array}$ & $\begin{array}{l}\text { 1) Formaldehyde } \\
\text { 2) Diethoxymethane }\end{array}$ & 40.8 & 1060 & $5 \%$ RF1 & 84.0 & 13.1 & 2.6 & 847 \\
\hline GF-O & $\begin{array}{c}\text { Glycerol Formal 1) } \\
\text { Oleate }\end{array}$ & $\begin{array}{c}\text { Formaldehyde } \\
\text { 2) Me Ester of rapeseed }\end{array}$ & 6.5 & 959 & $5 \%$ RF2 & 85.2 & 13.3 & 0.7 & 847 \\
\hline GF-L & $\begin{array}{c}\text { Glycerol Formal } \\
\text { Laurate }\end{array}$ & $\begin{array}{l}\text { 1) Formaldehyde } \\
\text { 2) Me Ester } C_{12}-C_{16}\end{array}$ & 21.2 & 970 & $10 \%$ RF2 & 83.8 & 13.2 & 2.7 & 855 \\
\hline GTBE & $\begin{array}{l}\text { Glycerol Ter } \\
\text { Butyl Ether }\end{array}$ & Isobutene & 25.0 & 917 & $\begin{array}{l}5 \% \text { RF1 } \\
5 \% \text { RF2 }\end{array}$ & $\begin{array}{l}85.8 \\
84.6 \\
\end{array}$ & $\begin{array}{l}13.1 \\
13.4 \\
\end{array}$ & $\begin{array}{l}1.3 \\
1.6 \\
\end{array}$ & $\begin{array}{l}848 \\
845 \\
\end{array}$ \\
\hline diGTBE & $\begin{array}{c}\text { di-Glycerol Ter } \\
\text { Butyl Ether }\end{array}$ & $\begin{array}{l}\text { 1) Glycerol condensation } \\
\text { 2) Isobutene }\end{array}$ & 25.9 & 959 & $10 \% \mathrm{RF} 2$ & 84.8 & 13.4 & 2.0 & 845 \\
\hline GTBEC & $\begin{array}{c}\text { Glycerol Ter } \\
\text { Butyl Ether Carbonate }\end{array}$ & $\begin{array}{l}\text { 1) Isobutene } \\
\text { 2) Diethylcarbonate }\end{array}$ & 28.3 & 960 & $5 \% \mathrm{RF} 1$ & 85.7 & 13.1 & 1.6 & 852 \\
\hline GPAC & $\begin{array}{c}\text { Carbonate of Glycerol } \\
\text { iso Propyl Acetal }\end{array}$ & $\begin{array}{l}\text { 1) Acetone } \\
\text { 2) Diethylcarbonate }\end{array}$ & 39.8 & 1140 & $5 \% \mathrm{RF} 1$ & 84.0 & 13.1 & 2.7 & 851 \\
\hline RME & Rapeseed Methyl Ester & - & 11.3 & 880 & $\begin{array}{c}5 \% \text { RF1 } \\
10 \% \text { RF2 }\end{array}$ & $\begin{array}{l}85.6 \\
84.7\end{array}$ & $\begin{array}{l}13.6 \\
13.3\end{array}$ & $\begin{array}{l}0.6 \\
1.5\end{array}$ & $\begin{array}{l}838 \\
848\end{array}$ \\
\hline
\end{tabular}

* Two different qualities of GBA have been obtained GBA1 still containing $0.2 \%$ glycerol and GBA2 in which all glycerol has been transformed. 


\section{GLYCEROL DERIVATIVES}

Starting from glycerol, which is intrinsically insoluble in Diesel fuel, we propose to develop chemical modifications intended to make it soluble and to introduce oxygenated functions potentially interesting for the required properties.

We have prepared different oxygenated glycerol derivatives and evaluated their emissions with different kinds of vehicles and engines (cf. Tab. 1).

The purpose was:

- To select the most interesting derivatives, from environmental and economical point of view;

- To test it more drastically;

- To propose the formulation of a new biofuel.

The chemistry of the glycerol compounds proposed here is, a priori, compatible with the quality of glycerol obtained with the transesterification process developed by IFP [12].

As the purpose was to include directly these glycerol derivatives in the Diesel pool, and not to use them with only some dedicated engines, they have been tested on Euro II and Euro III vehicles. The derivatives were blended into base fuels $\left(\mathrm{RF}_{1}, \mathrm{RF}_{2}\right)$, which are representative of European EN590 commercial Diesel fuel: $\mathrm{RF}_{1}$ was in use before $01 / 01 / 2005, R F_{2}$ for 2005 and after. Their main properties are given Table 2 .

TABLE 2

Reference fuel characteristics

\begin{tabular}{l|c|c}
\hline & $\mathrm{RF}_{1}$ & $\mathrm{RF}_{2}$ \\
\hline Density & $836 \mathrm{~kg} / \mathrm{m}^{3}$ & $842 \mathrm{~kg} / \mathrm{m}^{3}$ \\
\hline Cetane number & 52.3 & 54.8 \\
\hline Sulfur & $289 \mathrm{ppm}$ & $35 \mathrm{ppm}$ \\
\hline Oxygen & - & $0.35 \%$ \\
\hline Carbon & $86.3 \%$ & $85.9 \%$ \\
\hline Initial Point & $170.4^{\circ} \mathrm{C}$ & $200.6^{\circ} \mathrm{C}$ \\
\hline Final Point & $360^{\circ} \mathrm{C}$ & $364.2^{\circ} \mathrm{C}$ \\
\hline Aromatics & $28 \% \mathrm{~m}$ & $30 \% \mathrm{~m}$ \\
\hline
\end{tabular}

To evaluate the intensity of fuel impact, blends containing 5\% or 10\% Rapeseed Methyl Ester (RME) have been also tested. To be retained, glycerol derivatives have to reduce $\mathrm{PM}$ emissions more than RME blends, without increasing too much the $\mathrm{NO}_{\mathrm{x}}$ emissions. The oxygen content of these diesel fuels is not over $4.4 \mathrm{wt} \%$ which is quite low compared to the values studied in other papers ( $7 \mathrm{wt} \%$ for Natarajan et al. [6]), but EN590 upper limit for oxygen content is $5 \%$ wt.

\section{GLYCEROL DERIVATIVE SCREENING}

Blends with $\mathrm{RF}_{1}$ were used in Euro II vehicle (Veh1) and those with $\mathrm{RF}_{2}$, in Euro III vehicle (Veh2) (cf. Figs 2, 3). For the Euro III vehicles, there is no significant difference between the two reference fuels. They are so close to the Euro IV standard that they can give us an idea of the behaviour for these Euro IV vehicles.

As one can see, $\mathrm{CO}$ emissions (cf. Fig. 3) are not a problem, whatever the vehicle and the reference fuel are, CO emissions are always under Euro IV standard. So the discussion will be concentrated first on PM emissions and then on $\mathrm{NO}_{\mathrm{x}}$ emissions.

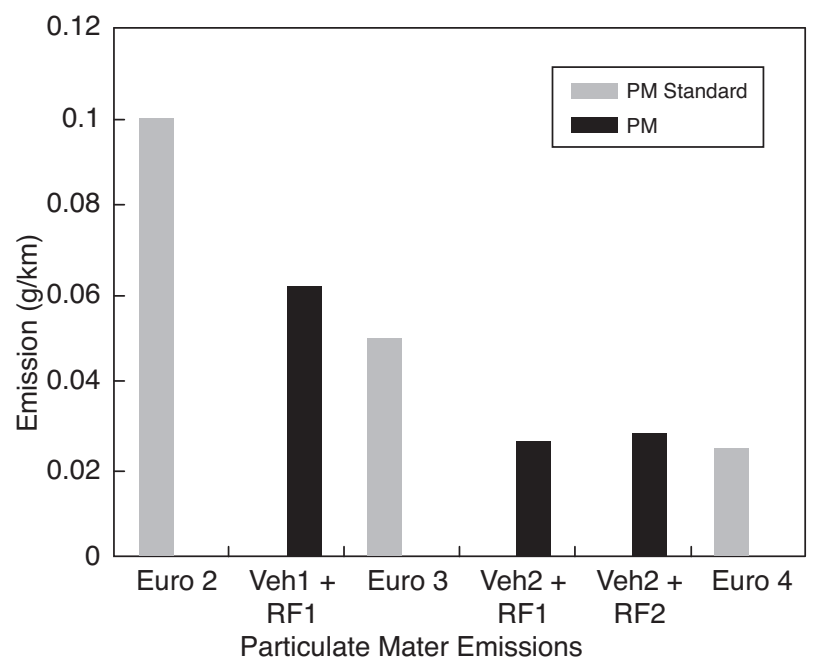

Figure 2

PM emissions with reference fuels and corresponding standards.

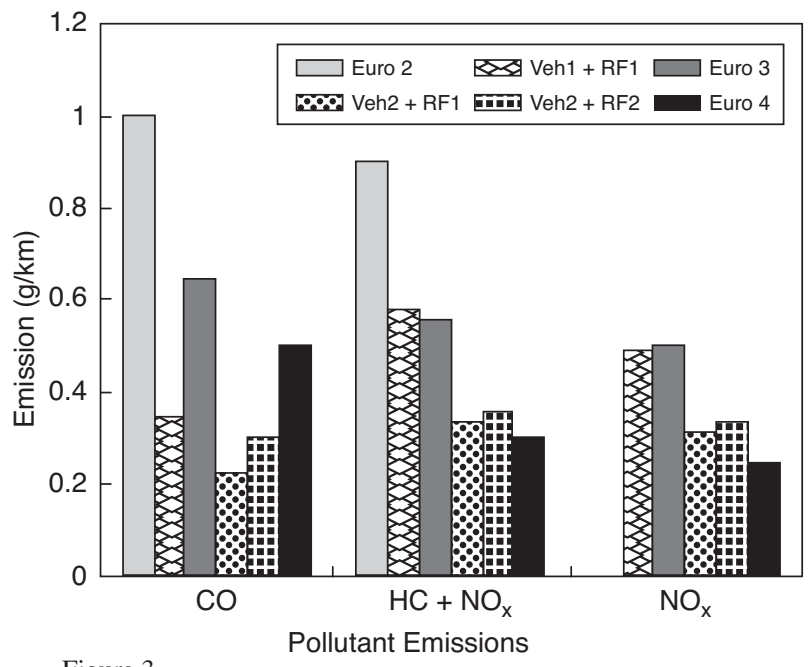

Figure 3

Pollutant emission with reference fuels and corresponding standards. 
All the tests were performed over the New European Driving Cycle (NEDC) the MVEG-11s driving cycle (Euro III). Each fuel was tested twice and additional test was decided only if the difference between the two runs was over $10 \%$ of standard values. The reference fuels were tested at the beginning, in the middle and at the end of the program for each vehicle to evaluate emissions measurement repeatability.

The main results are presented in Figures 4 and 5. Fuel impact has been evaluated as follow:

$$
\mathrm{FIp}=(\mathrm{Ep}(\mathrm{Oxy})-\mathrm{Ep}(\operatorname{Ref})) / \mathrm{Ep}(\operatorname{Ref}) \times 100
$$

where FIp: Fuel Impact for p pollutant, Ep(Oxy): p Emission with oxygenated fuel, $\mathrm{Ep}(\operatorname{Ref})$ : $\mathrm{p}$ Emission with reference fuel.

Fuel impact on $\mathrm{NO}_{\mathrm{x}}$ emissions is reported on $X$-axis, and $\mathrm{PM}$ impact on $Y$-axis. For this fuel screening, PM reduction was the key factor and $\mathrm{NO}_{\mathrm{x}}$ impact was only considered to separate two candidates with similar PM impact.

All the blends, even those containing only $5 \%$ glycerol derivatives, reduce PM emissions significantly by $15 \%$ to $25 \%$.

\subsection{Euro II Vehicles}

For Euro II vehicles (see Fig. 4), the most efficient blend contains 5\% GTBEC and reduces PM emissions by about $25 \%$, without increasing too much $\mathrm{NO}_{\mathrm{x}}$. This derivative is very interesting in term of pollutant emissions but its synthesis needs 2 steps versus only 1 for GTBE. It is the result of GTBE reaction with an excess of diethylcarbonate under basic conditions. This additional step involves higher manufacturing cost and penalizes the compound from "well to tank" $\mathrm{CO}_{2}$ emissions point of view. It could be more interesting to increase GTBE volume in the blend. In the same way, as there is no significant difference between GBA or GBAC impact, choice of GBA becomes obvious. GFEA and GPAC need one step more for their synthesis without increasing PM reduction. From a "well to tank" $\mathrm{CO}_{2}$ emissions point of view, they are eliminated from further screening.

In terms of $\mathrm{NO}_{\mathrm{x}}$ emissions, most of the impacts are in the range of measurement uncertainties, excepted GFEA-5\% and GEA-5\% which increase $\mathrm{NO}_{\mathrm{x}}$ emissions.

After the first screening with Euro II vehicles, three glycerol derivatives were retained for their performances: GTBE, GBA and GEA.

\subsection{Euro III Vehicle}

With Euro III vehicles (see Fig. 5), fuel impact on PM emissions are not as important as with Euro II vehicles. GEA which was very powerfull with Euro II vehicles don't have any significant effect on PM. It was probably not the good candidate. GTBE-5\% has quite the same impact as the fuel containing RME-10\% for reducing PM emissions. For $10 \%$ GTBE blend, one could expect about 20\% for PM reduction.

The blend with $10 \%$ GBA2, could be the requested glycerol derivative with $30 \%$ PM reduction. GBA1 and GBA2 differ only by their purification process which seems to be very important. GBA1 still contains $0.2 \%$ glycerol and there is no more glycerol in GBA2.

For $\mathrm{NO}_{\mathrm{x}}$ (Fig. 5), excepted GEA and diGTBE, which are quite bad, fuel impacts are not significant, they are in the range of measurement uncertainties.

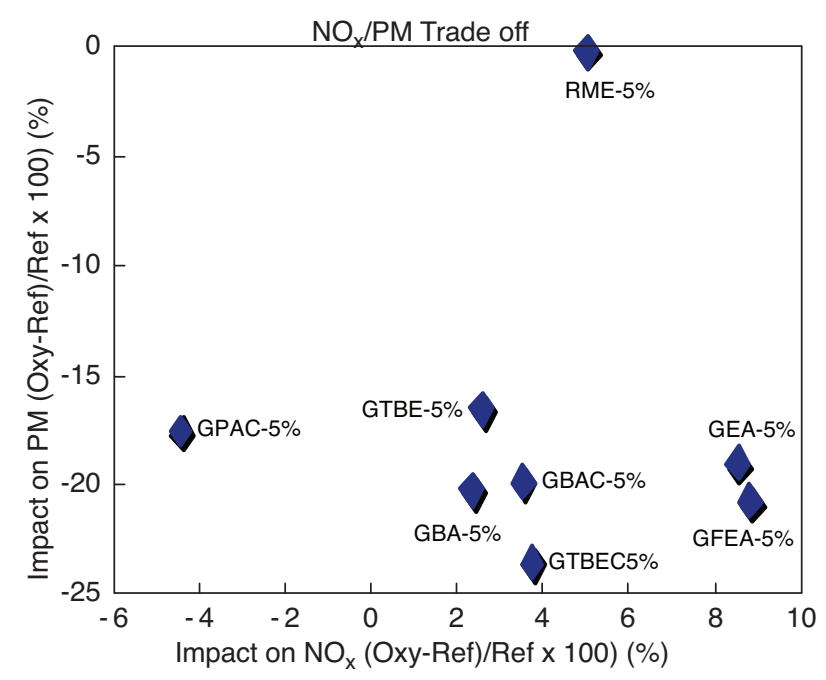

Figure 4

$\mathrm{NO}_{\mathrm{x}} / \mathrm{PM}$ Trade off - Euro II vehicles.

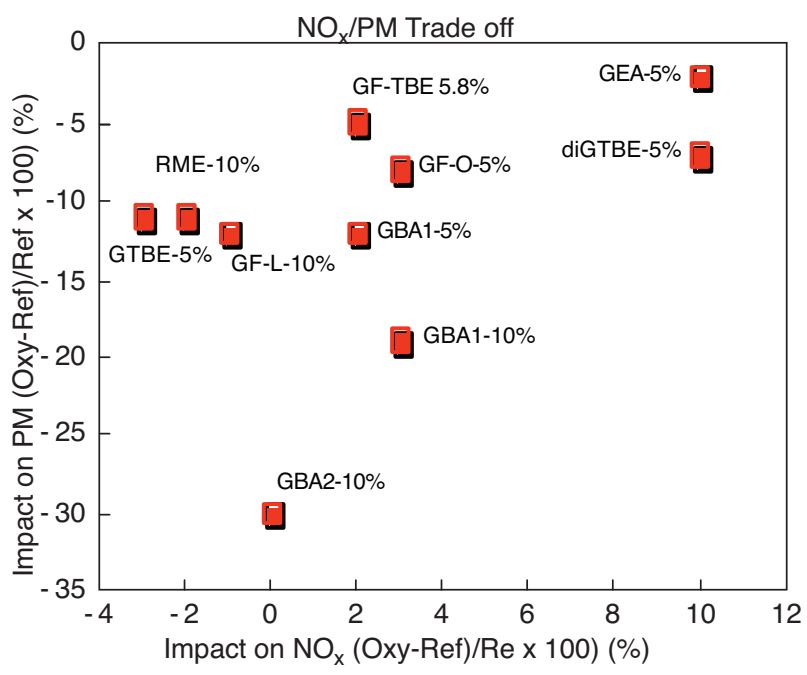

Figure 5

$\mathrm{NO}_{\mathrm{x}} / \mathrm{PM}$ Trade off - Euro III vehicles. 


\subsection{Assessment for Vehicle Tests}

Among the glycerol derivatives, it seems that a blend with $10 \%$ GTBE or GBA could be interesting to reduce PM emissions by more than $20 \%$ without too much penalizing $\mathrm{NO}_{\mathrm{x}}$ emissions.

From an economical point of view, it seems that the manufacturing cost of GBA could be twice the cost of GTBE [13]. GTBE is probably the best cost/efficiency glycerol derivative.

\section{$3.4 \mathrm{HCCl}$ Impact}

As the tests were performed on classical vehicle, it could be interesting to verify that GTBE will not penalize new engine technologies, such as HCCI engines which have very low $\mathrm{NO}_{\mathrm{x}}$ and particulate emissions. Nevertheless, to take more advantages of the HCCI concept, it is necessary to extend its application range in the engine speed and load domain. The tests have been done on an early injection HCCI single cylinder engine, NADI concept $[14,15]$ based on the AUDI V6 engine.

A specific fuel comparison procedure has been developed. It is based on the comparison of the HCCI operating ranges given for the different fuels. This HCCI area is delimited by acceptable HCCI operating conditions, which were defined by the following criteria (Tab. 3):

TABLE 3

HCCI acceptation criteria

\begin{tabular}{l|c|c}
\hline & $1500 \mathrm{rpm}$ & $2500 \mathrm{rpm}$ \\
\hline Maximum noise (dB) & 86 & 90 \\
\hline Maximum smoke level (FSN) & 2 & 2 \\
\hline Maximum indicated $\mathrm{NO}_{\mathrm{x}}$ emissions $(\mathrm{g} / \mathrm{kWh})$ & 0.1 & 0.1 \\
\hline Engine stability $(\mathrm{COV} \%)$ & $<5$ & $<5$ \\
\hline
\end{tabular}

At full load, under typical Diesel conditions (4000 rpm), some criteria have been also defined depending on incylinder pressure, smoke level, exhaust temperature, etc.

An HCCI index is calculated to quantify the impact of GTBE. This index is defined as follows [16]:

$$
\text { HCCI Ind. }=\frac{(\text { HCCIsurf })_{\mathrm{OXY}}}{(\text { HCCIsurf })_{\mathrm{RF} 2}} \times \frac{(\text { MaxLoad })_{\mathrm{OXY}}}{(\text { MaxLoad })_{\mathrm{RF} 2}} \times 100
$$

where "HCCIsurf" is the area defined for acceptable HCCI operating conditions and "MaxLoad" is the maximum load obtained in diesel conditions.

Blending $10 \% \mathrm{v}$. GTBE in reference fuel $\left(\mathrm{RF}_{2}\right)$ gives an HCCI index of 116. That means that adding 10\% GTBE could increase the HCCI range by $16 \%$, which is very interesting.
GTBE is a very promising glycerol derivative, but the benefits of blending GTBE in diesel fuel are not limited to its performance for reducing PM emissions. Transforming glycerol via GTBE also plays a part in the reduction of $\mathrm{CO}_{2}$ emissions. It could be considered as "biofuel" in the context of the new European directive. Such a product constitutes an outlet for glycerol, in the perspective of the development of biodiesel production.

\section{NEW BIOFUEL FORMULATION}

As we have seen before, glycerol is a fatal co product during RME process, but it can be transformed in GTBE which can be blended in diesel fuel. It could be interesting to synthesize GTBE in the same time as RME process and to introduce it into the biodiesel pool (cf. Fig. 6).

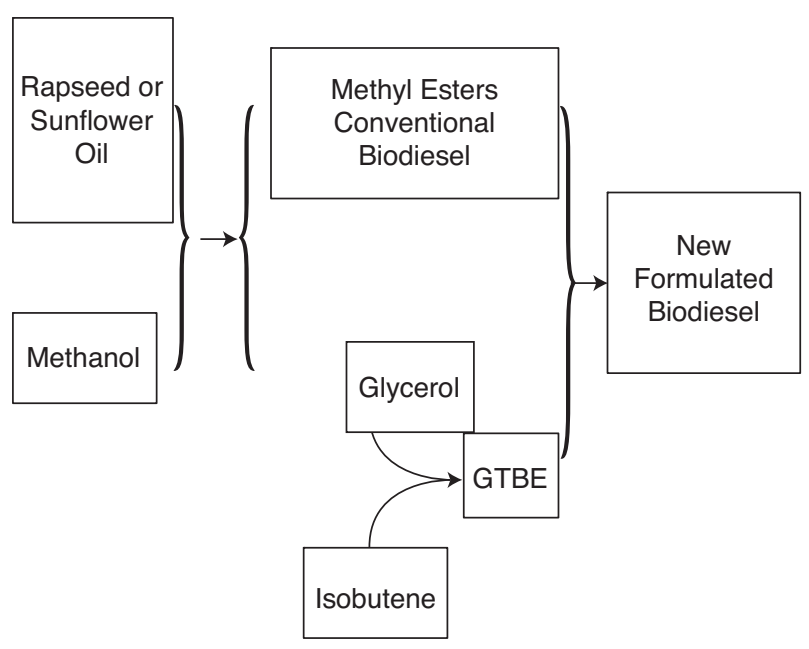

Figure 6

New biodiesel formulation.

\subsection{GTBE Synthesis}

First of all we have to optimize GTBE synthesis. In fact, what we call GTBE is not a single molecule, but it is a mixture of different kind of ethers (cf. Fig. 7).

Because isobutene is not a bio compound, we want to use it as little as possible. Increasing mono ether formation could be the most interesting way to reduce isobutene needs. But mono ethers are not soluble in Diesel fuel, contrary to di and tri ethers, so we have to reduce their concentrations. The 
synthesis conditions have been adjusted to increase di ethers formation. The composition of the best compromise is given in Table 4.

TABLE 4

GTBE composition

\begin{tabular}{c|c}
\hline Composition & \% GC area \\
\hline Mono t-butyl ethers & 13 \\
\hline Di t-butyl ethers & 64 \\
\hline Tri t-butyl ether & 22 \\
\hline Free Glycerol & 0.1 \\
\hline Di isobutene & 0.3 \\
\hline Analysis & $\mathrm{Wt} \%$ \\
\hline Carbone & 64 \\
\hline Hydrogen & 12 \\
\hline Oxygen & 23 \\
\hline Density & $912 \mathrm{~kg} / \mathrm{m}^{3}$ à $15^{\circ} \mathrm{C}$ \\
\hline
\end{tabular}

\subsection{New Biofuel Properties}

The production of $1.0 \mathrm{t}$. FAME induces $0.1 \mathrm{t}$. glycerol, which can produce about $0.22 \mathrm{t}$ GTBE. The extreme composition of the new biofuel could be $82 \% \mathrm{v}$. RME and $18 \% \mathrm{v}$. GTBE. But, in Europe, biodiesel must follow EN 14214 standards and this new biofuel has to comply with them, except for FAME content which must be above $96.5 \%$. Our objective was to formulate a new biofuel which has quite the same physico chemical properties as biodiesel.

As GTBE is a branched ether, its octane number is quite high [17] and then it has low cetane number (Its calculated blending cetane number is about 33 with $\mathrm{REF}_{1}$ ). Adding GTBE to biodiesel decreases its cetane number, but it is possible to compensate with pro cetane additives. Different formulations have been tested with three levels of pro cetane additive: without, $600 \mathrm{ppm}$ and $1000 \mathrm{ppm}$. As biodiesel cetane number can change depending on its composition, EN 14214 standard imposes minimum value (cetane number 51). To be sure that our formulation will be independent of biodiesel composition, we decided to use biodiesel cetane number itself rather standard cetane number, for our possible lowest limit (cf. Fig. 8).

The best formulation for cetane number was in Table 5 .

TABLE 5

New biodfuel formulation

\begin{tabular}{l|c|c}
\hline GTBE & 7.5 & $\%$ \\
\hline RME & 92.5 & $\%$ \\
\hline Ethyl-2-Hexyl Nitrate & 1000 & $\mathrm{ppm}$ \\
\hline
\end{tabular}

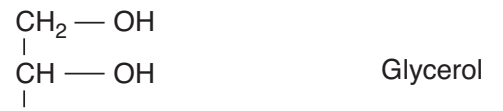

$$
\begin{aligned}
& \mathrm{H}_{2} \mathrm{C}=\mathrm{C}=\mathrm{CH}_{3} \downarrow \mathrm{CH}_{3} \downarrow \mathrm{H}^{+}
\end{aligned}
$$

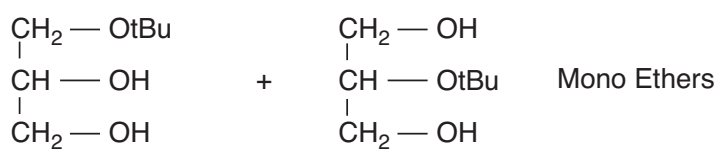

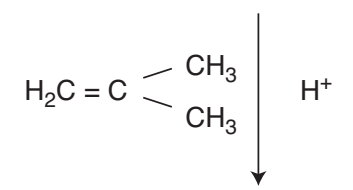

$$
\begin{aligned}
& \begin{array}{ll}
\mathrm{CH}_{2}-\mathrm{OtBu} & \mathrm{CH}_{2}-\mathrm{OH} \\
\mathrm{CH}-\mathrm{OH} & \mathrm{l} \\
\mathrm{CH} & \mathrm{CH}-\mathrm{OtBu} \quad \text { DI Ethers } \\
\mathrm{CH}_{2}-\mathrm{OtBu} & \mathrm{l} \mathrm{CH}_{2}-\mathrm{OtBu}
\end{array} \\
& \mathrm{H}_{2} \mathrm{C}=\mathrm{C}=\begin{array}{r}
\mathrm{CH}_{3} \\
\mathrm{CH}_{3}
\end{array} \downarrow \mathrm{H}^{+} \\
& \mathrm{CH}_{2}-\mathrm{OtBu} \\
& \mathrm{CH}-\mathrm{OtBu} \\
& \mathrm{CH}_{2}-\mathrm{OtBu} \\
& \text { with tBu : } \underset{\substack{\mathrm{C} \\
\mathrm{C}}}{\stackrel{\mathrm{C}}{\mathrm{C}}-\mathrm{H}_{3}} \mathrm{CH}_{3}
\end{aligned}
$$

Figure 7

Scheme of GTBE synthesis.

This formulation represents the highest GTBE quantity allowed without reducing biodiesel cetane number (with $1000 \mathrm{ppm}$ pro cetane additive).

This formulation is compatible with the EN 14214 standard excepted for RME content, which should be over $96.5 \%$. Oxidation stability is slightly decreased compared to pure RME, but it can be easily compensated with stability additive. There is no problem with density, viscosity, total contamination or cold properties.

This new formulation has been evaluated threw vehicle tests and engine tests. 


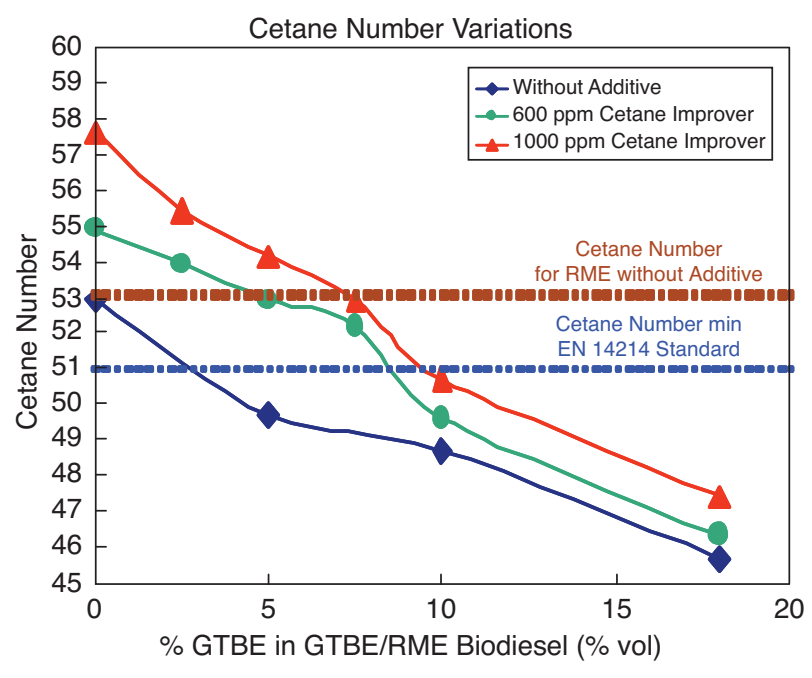

Figure 8

Impact of the GTBE concentration on the cetane number.

\section{EVALUATION OF NEW BIOFUEL}

\subsection{Engine Tests}

First of all the new formulation was tested on a DW4 Peugeot engine, 1.4HDI, 4 cylinders.

We have compared three fuels:

- A Low sulfur diesel fuel: "REF";

- 95\% REF + 5\% RME: "RME";

- $95 \% \mathrm{REF}+5 \%(92.5 \% \mathrm{RME}+7.5 \% \mathrm{GTBE}+1000 \mathrm{ppm}$ pro cetane): "RME + GTBE".

As one can see in Figures 9 and 10, engine performances at full load are very similar with the three fuels.

Including glycerol derivative in diesel fuel was suspected to increase injector fouling. We have proceeded to fouling tests using an IFP procedure, which accelerates injector fouling inducing some torque decrease and pollutant emissions change. Comparing engine performances, before and after this test, we observe a torque decrease of about $5 \%$ with the reference fuel. There is no difference between (RME) and (RME + GTBE) with a torque loss of 6\% (Fig. 11).

For pollutant emissions there is no significant difference between the three fuels. We can conclude that, from the engine point of view, there is no more problem with this new biofuel than with classical RME.

\subsection{Vehicle Tests}

Tests was done using a Citroën C3 (>7000 km) which was rented. All the tests were performed over the New European Driving Cycle (NEDC) the MVEG-11s driving cycle

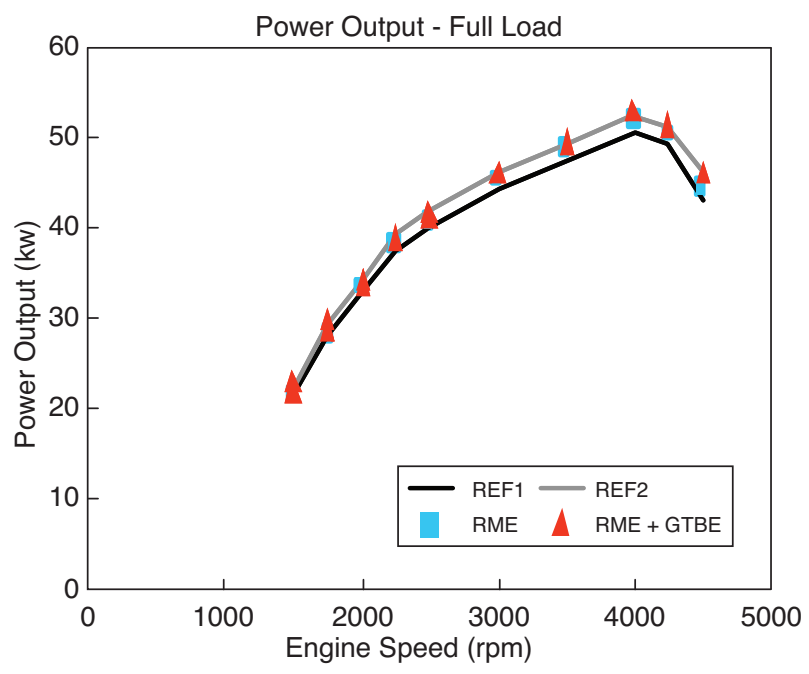

Figure 9

New biofuel impact at full load: power output.

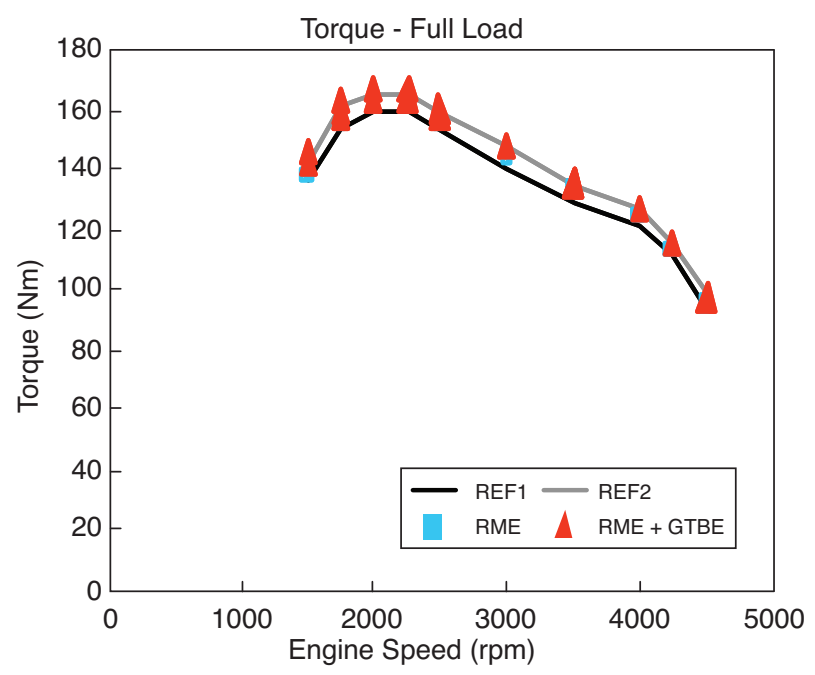

Figure 10

New biofuel impact at full load: Torque.

(Euro III). The impact of biofuels was calculated with the formula used for the glycerol derivative screening. For regulated pollutants (cf. Fig. 12) there is no significant difference between the two biofuels and the reference fuel. But we can notice that there is systematically a benefit using RME + GTBE fuel comparing to RME fuel.

Non regulated pollutants were also measured on ECE cycle, and we have focused on the toxic air pollutants (cf. Fig. 13). As it is well known, biofuels increase aldehyde formation, but the effect is more limited with RME + GTBE than with RME only. As the new biofuel reduces $\mathrm{HC}$ and aldehyde 


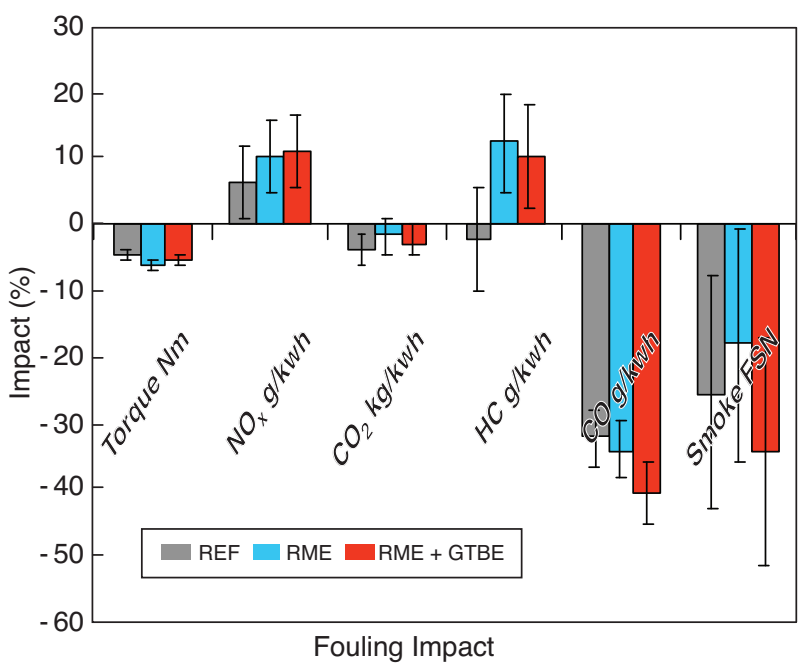

Figure 11

Injector fouling impact.

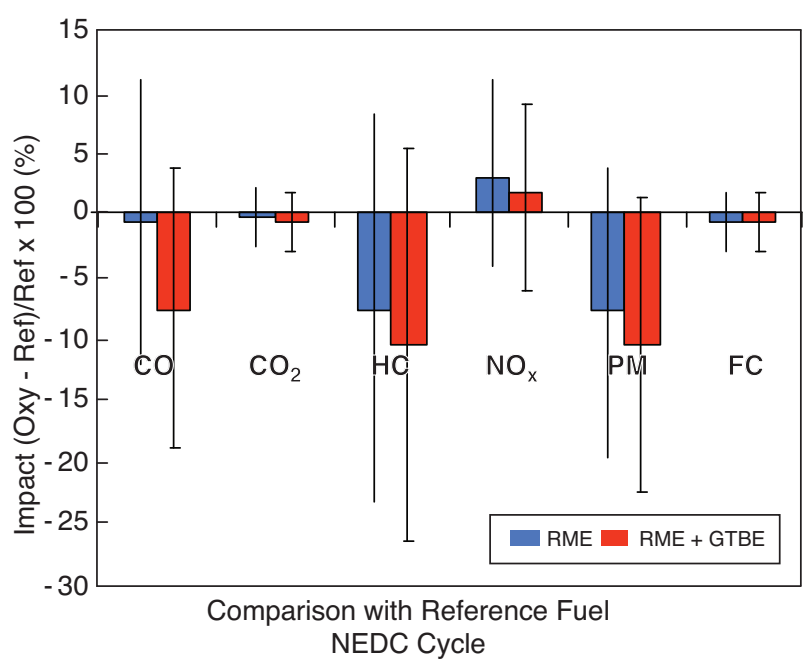

Figure 12

Impact on regulated pollutants.

emissions, its potential of ozone formation is lower than that of the reference. For benzene and 1,3-butadiene, even if it is more interesting to use the new biofuel, there is no significant difference between biofuels and reference fuels.

\section{CONCLUSION}

The objective of this work was to identify new outlet for glycerol. The idea was to find some glycerol derivative, soluble into Diesel fuel, which could be added directly to RME during the manufacture process.

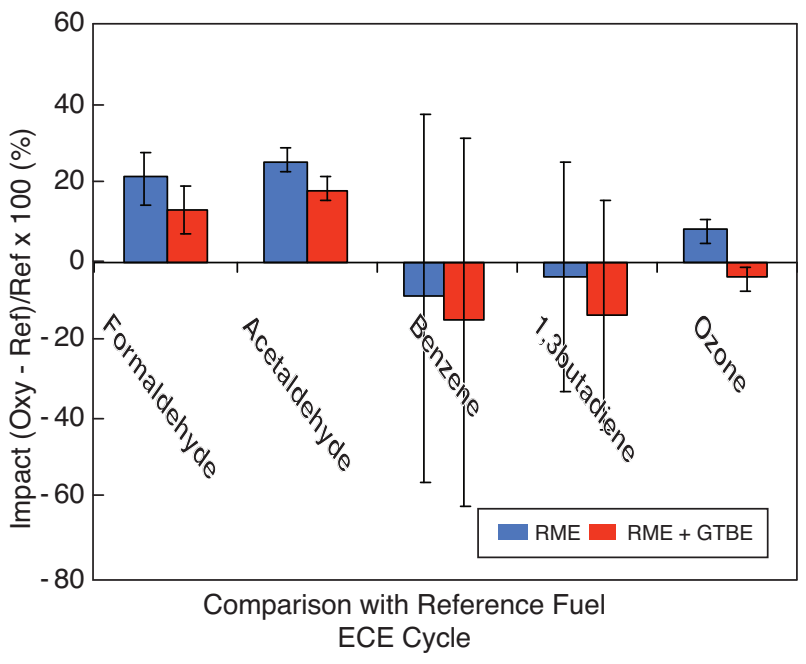

Figure 13

Impact on toxic air pollutants.

We have synthesized different glycerol oxygenated compounds, in particular acetals and ethers, and evaluated them on vehicles. From these glycerol derivatives, it seems that GTBE was the most interesting from pollutant emissions and economical point of view.

The benefits of blending GTBE in Diesel fuel are not limited to its performance for reducing PM emissions. However, transforming glycerol via GTBE plays a part in the $\mathrm{CO}_{2}$ emission reduction. It could be considered as "biofuel" in the context of the new European directive.

Using GTBE as basis to produce a new biofuel could be a promising way. This new biofuel was formulated with the respect of the physicochemical criteria required by EN14214 standard. These conditions were satisfied with an incorporation of $7.5 \%$ GTBE in RME, with the help of a reasonable additivation of cetane improver. This new biofuel was incorporated in diesel fuel (5\% in volume) and compared with a mixture containing 5\% RME. Various tests were carried out on vehicle and engine focusing on pollutant emissions and fouling problems. These tests allow us to conclude that the use of this new biofuel does not present any technical disadvantage. The decision to use GTBE in biofuel formulation will thus be controlled by economical criteria.

\section{ACKNOWLEDGMENTS}

The authors would like to acknowledge ADEME (Agence de l'Environnement et de la Maîtrise de l'Énergie) and ONIDOL (Organisation Nationale Interprofessionnelle des Oléagineux) for their technical and financial contribution to this project. 


\section{REFERENCES}

1 Majewski W.A. (2003) "Biodiesel”, Dieselnet Technology Guide - Alternative Diesel Fuels, http://www.dieselnet.com/ tech/fuel_biodiesel.html.

2 Sharp C.A., Howell S.A., Jobe J. (2000) The effect of biodiesel fuels on transient emissions from modern Diesel Engines - Part I: Regulated emissions and performance, SAE paper 2000-011967.

3 Babu A.K., Devaradjane G. (2003) Vegetable oils and their derivatives as fuels for $\mathrm{CI}$ engines: an overview, $S A E$ paper 2003-01-0767.

4 WWFC (2002) World Wide Fuel Charter, December 2002.

5 Directive 2003/30/EC of the European Parliament and of the Council of 8 May 2003 on the promotion of the use of biofuels or other renewable fuels for transport [Official Journal L 123 of 17.05.2003].

6 Natarajan M., Frame E.A., Naegeli D.W., Asmus T., Clark W., Garbak J., González D.M.A., Liney E., Piel W., Wallace J.P. (2001) Oxygenates for Advanced Petroleum-Based Diesel Fuels: Part 1. Screening and Selection Methodology for the Oxygenates, SAE paper 2001-01-3631.

7 Gonzalez D.M.A., Piel W., Asmus T., Clark W., Garbak J., Liney E., Natarajan M., Naegeli D.W., Yost D., Frame E.A., Wallace J.P. (2001) Oxygenates for Advanced Petroleum-Based Diesel Fuels: Part 2. The effect of oxygenate blending compounds on exhaust emissions, SAE paper 2001-01-3632.

8 Kitagawa H., Murayama T., Tosaka S., Fujiwara Y. (2001) The Effects of Oxygenated Fuel Additive on the Reduction of Diesel Exhaust Particulates, SAE paper 2001-01-2020.
9 Hiden D.L. (2001) The emissions performances of oxygenated Diesel fuels in a prototype Diesel engine, SAE paper 2001-010650 .

10 Md Nurum N., Masahiro M., Hideyuki O., Noboru M. (2000) Ultra low emissions and high performances Diesel combustion with highly oxygenated fuels, SAE paper 2000-01-0231.

11 Delfort B., Durand I., Jaecker-Voirol A., Lacôme T., Paillé F., Montagne X. (2002) Oxygenated compounds and Diesel Engine Pollutant Emissions: Performances of New Generation of products, SAE paper 2002-01-2852.

12 Bournay L., Chodorge J.A., Delfort B., Forestière A., Hillion G. (2002) New continuous process of biodiesel production. Biomasse for energy, industry and climate protection, 12th European Biomass conference, Amsterdam, 17-21 June 2002, Proceedings, Vol. 1, pp. 428-429.

13 Delfort B., Jaecker-Voirol A., Durand I., Hillion G., Montagne X. (2004) Glycerol derivatives for diesel fuels reformulation, IFP report 58419.

14 Duret P., Douaud A. (2001) New Combustion Processes: Homogeneous Diesel and Auto-Ignition Gasoline Towards Zero Emission with Major Engine and Fuel Technology Challenges, Global Powertrain Congress, Detroit, June 5-7.

15 Walter B., Gatellier B. (2003) Near zero $\mathrm{NO}_{x}$ emissions and high fuel efficiency diesel engine: the NADI ${ }^{\mathrm{TM}}$ concept using dual mode combustion, Oil Gas Sci. Technol. 58, 1, 101-114.

16 Forti L. (2004) Effect of fuel and additives on diesel HCCI engines, IFP International consortium Study, First year report.

17 Guibet J.C. (1997) Fuels and Engines, Technip edition.

Final manuscript received in April 2008 Published online in August 2008 